\title{
PERAN ORANG TUA DALAM MENANAMKAN SIKAP DISIPLIN PADA PEMBELAJARAN DI MASA PANDEMI KELAS IV SD N 02 KEMUTUG LOR
}

\author{
Dwi Cahyanto ${ }^{1^{*}}$ \\ Karma Iswasta Eka ${ }^{2}$ \\ ${ }^{1,2}$ Universitas Muhammadiyah Purwokerto, Purwokerto, Indonesia \\ dwicahyanto04@gmail.com ${ }^{1 *}$ \\ eka2001id@gmail.com ${ }^{2}$
}

\begin{abstract}
Abstrak
Penelitian ini berjudul "Peran Orang Tua Dalam Menanamkan Sikap Disiplin Pada Pembelajaran Di Masa Pandemi Kelas IV SD N 02 Kemutug Lor". Latar belakang penulis melakukan penelitian ini yaitu bagaimana peran orang tua dalam menanamkan sikap disiplin ketika pembelajaran di rumah. Penelitian ini bertujuan untuk mengetahui bentuk peran yang dilakukan oleh orang tua untuk mendampingi anak ketika melakukan pembelajaran jarak jauh, kendala yang dialami oleh orang tua dan solusi yang dapat diberikan oleh orang tua. Penelitian ini bersifat kualitatif deskriptif, dengan informan 4 orang tua kelas IV, 4 siswa kelas IV dan wali kelas IV. Teknik pengumpulan data menggunakan wawancara, observasi dan dokumentasi. Data yang diperoleh dianalisis dengan triangulasi sumber dan triangulasi teknik dan hasil penelitian disajikan dalam bentuk teks deskriptif. Hasil penelitian yaitu tua memberikan arahan dan pendampingan kepada anak supaya anak dapat selalu terkontrol ketika melaksanakan tugasnya. Peran orang tua ketika menanamkan sikap disiplin belajar yaitu memberikan arahan dan pendampingan kepada anak untuk selalu melakukan pembelajaran dan tugas sekolah dengan tepat waktu. Peran dukungan yang diberikan guru untuk menunjang sikap disiplin anak yaitu dengan memberikan contoh melakukan pembelajaran dengan tepat waktu, selalu berkomunikasi dengan orang tua terkait kondisi siswa. Kendala yang dialami orang tua yaitu kendala waktu yang berkaitan dengan orang tua yang memiliki pekerjaan, kendala terkait kurangnya penguasaan materi belajar oleh orang tua dan kondisi siswa yang masih senang bermain. Solusi yaitu selalu terjalinnya komunikasi yang baik oleh orang tua dengan anak dan guru.
\end{abstract}

Kata Kunci: Pembelajaran Jarak Jauh, Peran Orang Tua, Sikap Disiplin

Published by:

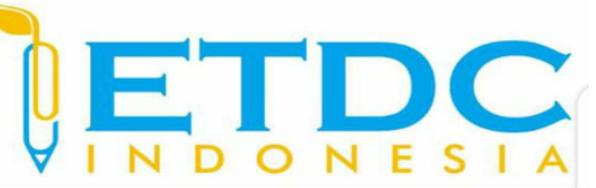

Copyright (C) 2021 The Author (s)

This article is licensed under CC BY 4.0 License

(cc) BY 


\section{PERAN ORANG TUA DALAM MENANAMKAN SIKAP DISIPLIN PADA PEMBELAJARAN DI MASA PANDEMI KELAS IV SD N 02 KEMUTUG LOR}

\section{Pendahuluan}

Pandemi yang sedang dirasakan saat ini menyebabkan hal baru dalam berbagai bidang di dunia ini seperti menggunakan alat digital yang semakin maju sebagai sarana untuk komunikasi. Pandemi COVID-19 saat ini sangat mengubah perilaku manusia ketika bersosialisasi, karena penggunaan alat digital berbasis internet untuk berkomunikasi. Virus COVID-19 di Indonesia saat ini berdampak bagi seluruh masyarakat. Dampak virus COVID19 terjadi di berbagai bidang seperti sosial, ekonomi, pariwisata dan pendidikan. Surat Edaran (SE) yang dikeluarkan pemerintah pada 18 Maret 2020 segala kegiatan didalam dan diluar ruangan di semua sektor sementara waktu ditunda demi mengurangi penyebaran corona terutama pada bidang pendidikan.

Menteri Pendidikan dan Kebudayaan Republik Indonesia mengeluarkan Surat Edaran Nomor 4 Tahun 2020 pada tanggal 24 Maret 2020 Tentang Pelaksanaan Kebijakan Pendidikan Dalam Masa Darurat Penyebaran COVID,dalam Surat Edaran tersebut dijelaskan bahwa proses belajar dilaksanakan di rumah melalui pembelajaran daring/jarak jauh dilaksanakan untuk memberikan pengalaman belajar yang bermakna bagi siswa. Belajar di rumahdapat difokuskan pada pendidikan kecakapan hidup antara lain mengenaipandemi Covid-19. Pandemi COVID19 membuat proses pembelajaran menjadi berubah drastis, karena yang sebelumnya pembelajaran dilakukan secara tatap muka langsung sedangkan sekarang pembelajaran melalui jaringan internet.

Pandemi COVID-19 mengakibatkan sistem pendidikan yang dialami saat ini mengalami dampak dari akibat pandemi COVID-19 yang belum kunjung usai sehingga proses pembelajaran tatap muka menjadi terganggu, dengan demikian pembelajaran yang dilaksanakan pada masa pandemi covid 19 menggunakan pembelajaran jarak jauh dengan berbasis internet. Sistem pembelajaran yang dilakukan menjadi berbeda, hal ini dikarenakan pendidikan harus tetap berjalan walaupun di masa pandemi saat ini.

Hatimah (Lilawati. A, 2021: 550) mengatakan bahwa pendidikan merupakan salah satu komponen yang sangat penting dalam kehidupan, guru merupakan salah seorang yang memiliki tanggung jawab besar, bukan berarti hanya kepada guru orang tua memasrahkan anak, namun keluarga dan orang tua juga memiliki tanggung jawab kepada proses pendidikan anak. Pendidikan merupakan seluruh tanggung jawab bersama antara pemerintah, sekolah (guru), dan 
keluarga (orang tua). Kelompok primer termasuk dalam sekolah dan keluarga. Pada kelompok primer terjadi interaksi sosial yang lebih intensif dan erat, yaitu face-to-face group, hal itu terjadi karena setiap anggota dari sering menghadapi atau bertatap muka yang satu dengan yang lain, sehingga membentuk karakter saling memahami dan memiliki hubungan yang saling erat.

Undang - Undang Sistem Pendidikan Nasional Tahun 2003 Nomor 20Bab 1 Pasal 1 Ayat 1 tertera bahwa, Pendidikan adalah usaha sadar dan terencana untuk mewujudkan suasana belajar dan proses pembelajaran agar peserta didik secara aktif mengembangkan potensi dirinya untuk memiliki kekuatan spiritual keagamaan, pengendalian diri, kepribadian, kecerdasan akhlak mulia, sertaketerampilan yang diperlukan dirinya, masyarakat, bangsa dan negara.

Pembelajaran jarak jauh adalah kegiatan belajar mengajar yang diperuntukan siswa dengan guru yang tidak terpisah jarak di suatu tempat secara rutin untuk memperoleh pelajaran. Pembelajaran jarak jauh dalam pelaksanaanya menggunakan bahan-bahan dan instruksiinstruksi detail yang bersifat khususyang dikirimkan atau disediakan untuk para peserta dan selanjutnyamelaksanakan tugas-tugas yang akan dievaluasi oleh guru. Pembelajaran jarak jauh yang dilaksanakan harus diawasi oleh guru, sehingga pembelajaran jarak jauh ini dapat terlaksana dengan baik.

Pembelajaran jarak jauh dalam pelaksanaannya ada beberapa faktor penting yang harus diperhatikan, agar sistem pendidikan (pembelajaran) jarakjauh dapat berjalan dengan baik, yakni perhatian, percaya diri pendidik, pengalaman, mudah menggunakan peralatan, kreatif menggunakan alat, dan menjalin interaksi dengan peserta didik. Pelaksanaan pembelajaran jarak jauh ini adalah salah satu solusi dari pemerintah agar pembelajaran dapat terlaksana dengan baik, namun dalam pelaksanaan pembelajaran daring ini banyak hal yang harus diperhatikan salah satunya yaitu perhatian dari orang tua yang harus lebih mengawasi anaknya sehingga pembelajaran yang dilaksanakan dapat berjalan dengan efektif dan efisien.

Pembelajaran jarak jauh merupakan salah satu kegiatan pembelajaran dimana pelaku pembelajaran tidak bertemu secara langsung. Pembelajaran inidapat menimbulkan masalahmasalah baru bagi siswa maupun guru, namun siswa akan sangat berdampak dalam menerima materi dari guru. Orang tua adalah salah satu yang memiliki peran penting mendampingi dalam pembelajaran jarak jauh.

Irma et al (Lilawati, Agustien, 2021: 550) dalam penelitian tersebut mendapatkan bahwa keterlibatan orang tua perlu disinergikan dengan berbagai upaya program dan kegiatan yang disesuaikan dengan analisis kendala orang tua meliputi faktor status sosial, faktor bentuk keluarga, faktor tahapan perkembangan keluarga, dan role model. faktor-faktor tersebut, sehingga dapat dikatakan bahwa keluarga memiliki peran yang besar dalam proses pendidikan 
anak.

Keluarga merupakan pondasi pendidikan yang pertama bagi anak,Hayati (Lilawati. A, 2021: 550) dikatakan bahwa sikap orang tua sangat membantu dalam mengembangkan potensi anak, termasuk menghargai pendapat anak dan mendorong anak untuk mengatakannya, memberikan kesempatan kepada anak untuk berefleksi, berfantasi, berfikir, dan memungkinkan anak mengambil keputusan secara individu. Keluarga juga berperan dalam memberikan rangsangan kepadanya sehingga ia selalu banyak bertanya dan memberikan penguatan kepada anak bahwa sikap orang tua menghargai perasaan ingin mencoba hal-hal baru.

Orang tua harus memiliki sikap menghargai dari perilaku yang dilaksanakan dan menghasilkan, menunjang dan mendorong kegiatan anak, menikmati keberadaannya bersama anak, memberi sanjungan yangsungguh-sungguh kepada anak, mendorong kemandirian anak dalam bekerja dan menjalin hubungan kerja sama yang baik dengan anak. Orang tua merupakan pendorong yang paling penting dari lingkungan keluarga sehinggasegala faktor dalam keluarga sangat berpengaruh dalam perkembangan anak, apalagi sekarang anak menerima pembelajaran yang dominan dilaksanakan dirumah sehingga orang tua perlu memberikan peranan yang lebih terhadapanak.

Keluarga adalah tempat yang paling efektif untuk perkembangan anak, karena keluarga merupakan tempat untuk anak bermain dan belajar. Lingkungan keluarga yang diciptakan oleh orang tua akan berdampak pada perkembangan anak, hal ini disebabkan lingkungan yang diciptakan menyenangkan akan berdampak baik kepada anak sedangkan lingkungan yang diciptakan kurang baik akan berdampak buruk kepada perkembangan anak juga. Lingkungan keluarga yang tercipta itu merupakan pondasi awal untuk perkembangan anak dalam berfikir dan bersosialisasi.

Nurlaeni dan Juniarti (Lilawati. A, 2021: 551) menyebutkan orang tua pada awalnya berperan dalam membimbing sikap serta keterampilan yang mendasar, seperti pendidikan agama untuk patuh terhadap aturan, dan untuk pembiasaan yang baik, namun perannya menjadi meluas yaitu sebagai pendamping pendidikan akademik. Prabawani (Lilawati.A, 2021: 551) menyatakan bahwa pelaksanaan pendidikan merupakan tanggung jawab orang tua dan masyarakat sekitar, tidak hanya tanggungjawab lembaga pendidikan saja. Orang tua adalah bagian dari keluarga yang berperan besar terhadap perkembangan anak, mereka bertanggung jawab atas pendidikan, perawatan dan bimbingan anak-anak mereka untuk kehidupan sosial.

Gunarsa (Lilawati. A, 2021: 551) berpendapat bahwa keluarga ideal (sempurna) memiliki dua orang yang memainkan peran penting, yaitu, sebagai ayah dan ibu. Peran seorang ibu adalah untuk memenuhi kebutuhan secara biologis dan fisik anaknya, bersabar, kasih 
sayang dan ketabahan dalam merawat keluarga, mendidik, mengelola dan mengendalikan anak-anak, dan memberikan contoh bagi anak-anak. Peran ayah yaitu ayah sebagai sumber Tuhan, ayah sebagai konsep dan asuransi untuk suami, ayah berpartisipasi dalam pendidikan anak dan ayah sebagai wali, bijak atau hormat dari keluarga. Orang tua memiliki peran penting dalam kasih sayang yaitu memberikan kebutuhan secara lahir dan batin untuk anaknya, sehingga perkembangan anak dan kondisi anak sangat dipengaruhi oleh kondisi orangtuanya.

Wujud peran orang tua sebenarnya merupakan wujud peran guru ketika berada di lingkungan sekolah. Peran orang tua adalah mampu memotivasi anak dalam segala hal. Peran orang tua adalah membimbing dan memberikan motivasi kepada anak, agar anak tetap bersemangat dalam melakukan kegiatan di rumah. Yulianti (Lilawati. A, 2021: 552) menyatakan pada dasarnya anak memiliki motivasi untuk melakukan suatu hal, apabila ia mendapatkan sebuah dorongan dari orang-orang terdekat seperti orang tua. Penghargaan yang diberikan kepada anak besar maupun kecil itu sangat berpengaruh, penghargaan yang diberikan sangat berharga dan lebih antusias untuk anak-anak.

Orang tua juga bisa menjadi teman bahagia untuk belajar. Orang tua juga ditugaskan sebagai guru untuk mengajar dan mendidik anak-anak mereka. Orang tua sangat berperan penting dalam pembelajaran anak oleh karena itu, orang tua perlu lebih sabar dalam mengajar dan membimbing sebagai tugas guru di sekolah. Orang tua harus saling melengkapi dan membantu dalam memecahkan masalah dan kesulitan yang dihadapi anak-anak di sekolah dan di rumah. Gusmaniarti dan Suweleh (Lilawati.A, 2021: 552) memiliki pendapat yang hampir sama yaitu mendapati orang tua mempunyai peran dalam mengembangkan rasa percaya anak walaupun sebagian kecil masih ada yang mendampingi.

Peran orang tua sebagai fasilitator disiplin bagi anak adalah menanamkan dan menegakkan disiplin di lingkungan rumah. Disiplin anak memang penting, tapi bukan berarti disiplin yang menekan dan ketat. Anak-anak hanya perlu terbiasa dengan kehidupan yang terarah dan teratur. Disiplin memang merupakan hal yang harus ada dalam anak sehingga orang tua harus bisa berperan penting dalam mendampingi anak berperilaku di rumah. Orang tua selalu memberikan contoh kedisiplinan kepada anak sehingga anak akan memiliki kesadaran dari kedisiplinan yang dicontohkan orang tua.

Peran orang tua berkenaan dengan upaya peningkatan nilai, orang tua dapat membuat jadwal tugas belajar di rumah dan jadwal belajar mereka. Anak merasa disiplin ketika diterapkan secara teratur dari waktu ke waktu. Peran orang tua membuat jadwal membuat anak tidak merasa terikat dengan aturan, tetapi anak melakukannya dengan kesadaran diri. Kesadaran diri dalam anak dapat timbul ketika orang tua mampu memberi contoh yang benardalam 
kedisiplinan ketika berada di rumah. Orang tua dengan pendampingan yang baik kepada anak ketika di rumah maka akan berdampak baik pada perkembangan sikap anak kedepannya.

Peran orang tua sebagai pengelola adalah agar orang tua dapat melacak perkembangan kinerja anaknya dan mengontrol perilakunya di rumah dan di sekolah dengan pendekatan informasi antara guru dan orang tua, oleh karena itu orang tua dapat menentukan alasan perkembangan anak mereka, regresi dan merespon dengan bijak. Motivasi yang diberikan oleh orang tua sebagai ibu atau ayah mereka juga harus berperan seperti guru yang ada di sekolah dengan pemberian motivasi yang semestinya diberikan kepada anak usia sekolah dasar sehingga anak dapat berkembang dengan baik walaupun melakukan pembelajaran dirumah sehingga mereka memiliki sifat disiplin dalam kehidupan nyata.

Peneliti melakukan observasi serta wawancara pendahuluan dengan guru kelas IV di SD Negeri 2 Kemutug Lor mengenai permasalahan apa saja yang timbul di kelas. Beberapa masalah disampaikan kepada peneliti terkait kegiatan belajar mengajar secara daring yang dilakukan di kelas IV SD Negeri 02 Kemutug Lor. Berdasarkan wawancara pendahuluan dengan guru kelas IV didapatkan bahwa permasalahan yang sering terjadi adalah mengenai kedisiplinan siswa menurun ketika adanya kebijakan dari rumah. Kedisiplinan terkait melakukan presensi, pengumpulan tugas, dan aktif dalam diskusi yang dilakukan ketika kegiatan belajar mengajar berlangsung.

Orang tua adalah sosok yang mendampingi dan mengarahkan siswa ketika kegiatan belajar mengajar berlangsung. Orang tualah yang dengan secara langsung dapat memberikan contoh maupun mengarahkan siswa untuk berlaku disiplin pada kegiatan belajar mengajar dibandingkan dengan guru. Berdasarkan permasalahan mengenai proses pendidikan yang dilaksanakan secara jarak jauh karena adanya pandemi COVID-19 sehingga menyebabkan timbulnya permasalahan yang diangkat oleh peneliti mengenai peran orang tua menerapkan sikap disiplin dalam pembelajaran jarak jauh di SD Negeri 2 Kemutug Lor, maka peneliti ingin mengkaji terkait peran orang tua menerapkan sikap disiplin dalam pembelajaran jarak jauh, Peran orang tuadalam menerapkan sikap disiplin kepada anak dan kendala yang dihadapi orang tua dalam mendampingi anak melakukan pembelajaran jarak jauh.

\section{Metode Penelitian}

Penelitian yang dilakukan merupakan penelitian kualitatif deskriptif. Peneliti melakukan penelitian di kelas IV SD N 02 kemutug Lor dan informan dalam penelitian ini adalah 4 orang tua siswa kelas IV, 4 siswa kelas IV dan wali kelas IV. Penelitian yang dilakukan menggunakan teknik pengumpulan data yaitu wawancara, observasi dan dokumentasi. Data 
yang diperoleh kemudian dianalsis dengan triangulasi sumber dan triangulasi teknik dan hasil penelitian disajikan dalam bentuk teks deskriptif.

\section{Hasil dan Pembahasan}

\subsection{Peran orang tua dalam pendampingan anak pada proses pembelajaran jarak jauh di} SD N 02 Kemutug Lor.

Peran orang tua dalam pembelajaran jarak jauh itu merupakan hal yang sangat penting, hal ini dikarenakan guru tidak bisa mengawasi siswa secara langsung ketika pembelajaran, oleh karena itu penting sekali bahwa kesadaran orang tua sangat diperlukan untuk membimbing anak supaya bisa mengikuti pembelajaran secara efektif. Peran orang tua dalam bentuk apapun itu sangat berpengaruh kepada perilaku anak ketika pembelajaran.

Hasil penelitian tentang peran yang dilakukan orang tua terhadap pembelajaran jarak jauh di SD N 02 Kemutug Lor menunjukan bahwa orang tua sangat berperan penting untuk mengontrol perilaku anak dalam pembelajaran jarak jauh. Peran yang diberikan oleh orang tua yaitu memberikan pendampingan kepada siswa ketika siswa mengalami kesulitan dalam menerima pembelajaran. Orang tua memberikan arahan ketika anak mengalami kesulitan dalam mengerjakan tugas oleh karena itu orang tua mengajari anak untuk bisa memahami materi yang sedang dilaksanakan sehingga anak bisa memahami dan bisa mengerjakan tugas belajar. Pendapat orang tua ini sesuai dengan Winingsih (Wijayanti, R. M., Fauziah, P. Y., 2020: 1307) menyatakan peran orangtua dalam Pembelajaran Jarak Jauh salah satunya yaitu orang tua memiliki peran sebagai guru di rumah, karena orang tua dapat membimbing anak dalam belajar secara jarak jauh dari rumah.

Orang tua ketika melakukan pendampingan dalam kegiatan pembelajaran jarak jauh terhadap anak tentunya harus memiliki sifat tegas, sifat tegas ini bertujuan untuk membuat anak untuk tetap percaya bahwa orang tua bisa untuk membimbing dirinya ketika melakukan pembelajaran jarak jauh. Pendampingan orang tua secara tegas akan membuat anak lebih semangat untuk belajar walaupun belajar dengan metode jarak jauh. Peneliti juga menemukan peranan yang dilakukan oleh orang tua kepada anak ketika pembelajaran jarak jauh di SD N 02 Kemutug Lor yaitu orang tua melakukan pendampingan kepada siswa dengan selalu menyediakan kebutuhan siswa ketika pembelajaran akan berlangsung. Peran yang dilakukan oleh orang tua kepada anak yaitu dengan selalu memperhatikan kesulitan yang dialami anak, ketika anak mengalami kesulitan orang tua langsung sigap mengambil tindakan yaitu dengan berkomunikasi dengan guru langsung sehingga orang tua menjadi tahu bagaimana tindakan selanjutnya ketika anak mengalami kendala. 
Peran orang tua dalam memberikan pendampingan tidak hanya komunikasi dengan guru saja melainkan orang tua siswa juga mendampingi dan menyediakan kebutuhan siswa. Kebutuhan siswa ini seperti buku yang menunjang untuk kegiatan belajar di rumah sehingga persiapan anak untuk mengikuti pembelajaran bisa terkendali dan dipersiapkan dengan matang oleh orang tua. Hasil analisis data temuan ini juga sesuai dengan Winingsih (Wijayanti, R. M., Fauziah, P. Y., 2020: 1307) menyatakan bahwa orang tua sebagai fasilitator, yaitu orang tua sebagai sarana dan prasarana bagi anaknya dalam melaksanakan pembelajaran jarak jauh.

Penelitian yang telah dilakukan menemukan temuan bahwa peran yang dilakukan oleh orang tua kepada anak yaitu orang tua selalu memberikan pendampingan secara teratur dengan selalu melakukan arahan kepada perilaku siswa ketika pembelajaran, orang tua juga selalu memberikan masukan ketika anak sedang melakukan pembelajaran dengan memberikan pengertian bahwa pendidikan itu sangat penting sehingga anak harus tetap selalu belajar sehingga nilai yang diperoleh tidak akan turun walaupun pembelajaran menggunakan metode jarak jauh. Arahan dan masukan yang diberikan oleh orang tua bertujuan untuk memotivasi anak agar tetap semangat dalam belajar. Hasil analisis data temuan ini juga sesuai dengan Winingsih (Wijayanti, R. M., Fauziah, P. Y., 2020: 1307) menyatakan bahwa orang tua sebagai motivator, yaitu orang tua dapat memberikan semangat serta dukungan kepada anaknya dalam melaksanakan pembelajaran, sehingga anak memiliki semangat untuk belajar, serta memperoleh prestasi yang baik.

\subsection{Peran orang tua dalam menanamkan sikap disiplin dalam proses pembelajaran jarak jauh di SD N 02 Kemutug Lor.}

Sikap disiplin adalah sikap yang sangat perlu dimiliki siswa, apalagi didalam waktu sekarang ini saat pandemi Covid 19 yang menyebabkan pembelajaran bersifat jarak jauh. Untuk menanamkan sikap disiplin kepada siswa perlu pendampingan dari orang tua supaya siswa dapat optimal dalam melakukan sikap disiplin dalam pembelajaran jarak jauh, oleh karena itu sangat penting sekali orang tua untuk mengetahui peranan yang harus dilakukan untuk pendampingan anak dalam sikap disiplin.

Hasil penelitian yang telah dilakukan dalam peran orang tua dalam menanamkan sikap disiplin dalam pembelajaran jarak jauh di SD N 02 Kemutug Lor menjelaskan bahwa ketepatan waktu itu sangat penting karena pembelajaran yang dilaksanakan secara online sehingga orang tua harus bisa memberikan pendampingan kepada anak. Orang tua melakukan pendampingan ketepatan waktu dalam pembelajaran jarak jauh yaitu dengan selalu memberikan arahan kepada anak untuk selalu tepat waktu dalam mengerjakan tugas dan dikirim sebelum waktu yang ditentukan habis. Orang tua harus selalu mengawasi supaya anak bisa mengikuti pembelajaran 
dengan efektif.

Peran orang tua ketika mengawasi anak seharusnya bisa membimbing anak untuk memastikan bahwa anak bisa mengikuti pembelajaran dengan baik dan bisa mengerjakan tugas secara tepat waktu. Peran orang tua untuk menanamkan sikap disiplin dalam pembelajaran juga didukung oleh guru dengan pelaksanaan pembelajaran yang selalu diusahakan oleh guru dengan pelaksanaan pembelajaran yang dilakukan tepat waktu sehingga secara tidak langsung mengajarkan siswa untuk berperilaku disiplin dalam pembelajaran. Hasil analisis data ini sesuai dengan pendapat Shochib (Mubarok, M. S, 2017: 54), ketika perilaku siswa yang dapat digunakan untuk mengukur tingkat kedisiplinan belajar siswa di sekolah. Sikap disiplin bisa dilihat berdasarkan ketentuan disiplin waktu dan disiplin perbuatan, yaitu tepat waktu.

Hasil penelitian yang dilakukan ditemukan fakta bahwa pembelajaran jarak jauh yang dilaksanakan membuat siswa lebih memiliki sifat malas sehingga anak hanya berpikir untuk bermain saja, oleh karena itu orang tua harus bisa memberikan pendampingan kepada anak. Pendampingan yang dilakukan yaitu selalu memberi arahan kepada anak untuk selalu mengerjakan tugas terlebih dahulu baru diperbolehkan pergi bermain oleh orang tua. Perang orang tua yang diberikan diharapkan membuat siswa untuk memiliki sikap disiplin dalam mengikuti pembelajaran, Hasil temuan ini sesuai dengan pendapat Shochib (Mubarok, M. S, 2017: 54), ketika perilaku siswa yang dapat digunakan untuk mengukur tingkat kedisiplinan belajar siswa di sekolah. Sikap disiplin bisa dilihat berdasarkan ketentuan disiplin waktu dan disiplin perbuatan, tidak meninggalkan kelas atau membolos saat pelajaran.

Hasil penelitian yang dilakukan menemukan temuan kembali tentang kondisi siswa ketika pembelajaran yaitu memiliki sifat malas, sehingga orang tua harus bisa berperan dalam membimbing anak untuk memiliki sikap disiplin pada diri sendiri yaitu sikap mandiri. Sikap mandiri yang dimiliki oleh anak bertujuan untuk membuat siswa tetap semangat dalam melaksanakan pembelajaran jarak jauh, hal ini sesuai dengan pendapat Shochib (Mubarok, M. S, 2017: 54), ketika perilaku siswa yang dapat digunakan untuk mengukur tingkat kedisiplinan belajar siswa di sekolah. Sikap disiplin bisa dilihat berdasarkan ketentuan disiplin waktu dan disiplin perbuatan, tidak malas belajar.

Hasil penelitian yang telah dilaksanakan menemukan beberapa temuan berupa anak harus bisa menaati peraturan yang telah diberikan oleh guru. Anak untuk bisa menaati peraturan yang diberikan oleh guru orang tua harus melakukan bimbingan kepada anak dengan memberikan pengertian dan arahan ketika akan melaksanakan pembelajaran, sehingga selain orang tua menyiapkan kebutuhan anak, anak juga menyadari bahwa dirinya memiliki tanggung jawab untuk kesadaran diri sebelum mengikuti pembelajaran seperti sudah makan, sudah mandi 
sehingga anak siap untuk mengikuti pembelajaran, hasil analisis data ini sesuai dengan pendapat Shochib (Mubarok, M. S, 2017: 54), ketika perilaku siswa yang dapat digunakan untuk mengukur tingkat kedisiplinan belajar siswa di sekolah. Sikap disiplin bisa dilihat berdasarkan ketentuan disiplin waktu dan disiplin perbuatan, yaitu menaati peraturan sekolah.

Hasil penelitian yang telah dilaksanakan di SD N 02 Kemutug Lor mendapati temuan bahwa pendampingan yang dilakukan orang tua untuk menanamkan sikap disiplin dalam pembelajaran jarak jauh itu berupa bimbingan yang dilakukan secara langsung oleh orang tua. Pendampingan yang dilakukan oleh orang tua bersifat arahan yang diberikan langsung terhadap anak untuk membuat anak bisa menerapkan sikap disiplin belajar dengan selalu tepat waktu dalam pembelajaran dan pengerjaan tugas. Peran pendampingan sikap disiplin dalam pembelajaran mengajarkan anak tidak meninggalkan pembelajaran untuk pergi bermain, sehingga akan terbentuk kebiasaan dalam diri anak untuk memiliki sikap disiplin dalam diri sendiri yaitu seperti sifat mandiri.

Hasil penelitian yang telah dilakukan dan berdasarkan temuan yang dilakukan oleh peneliti, hal ini sesuai dengan pendapat Nugroho (Akmaluddin, Haqqi, 2019: 6) mengemukakan bahwa agar seorang siswa dapat belajar dengan baik, maka ia harus bersikap disiplin. Kedisiplinan merupakan awal dari ketaatan siswa sesuai dengan aturan yang berlaku, terutama kedisiplinan belajar dalam kedisiplinan waktu belajar, kedisiplinan untuk tidak meninggalkan pembelajaran, kedisiplinan dalam diri sendiri.

\subsection{Kendala-kendala yang dialami orang tua dalam pendampingan penanaman sikap disiplin dalam proses pembelajaran jarak jauh di SD N 02 Kemutug Lor}

Hasil penelitian yang telah dilaksanakan di SD N 02 Kemutug Lor menemukan temuan bahwa kendala yang dialami oleh orang tua dalam pendampingan penanaman sikap disiplin pertama yaitu dari kendala waktu. Kendala waktu yang dialami oleh orang tua itu berkaitan dengan faktor pekerjaan dari orang tua, ketika orang tua yang memiliki pekerjaan pastinya harus bisa membagi waktu untuk bisa mendampingi anak. Kendala waktu ini menyebabkan orang tua tidak bisa selalu mendampingi anak untuk menerapkan sikap disiplin ketika pembelajaran ataupun tugas dari guru. Hasil analisis data temuan ini sesuai dengan pendapat. Nugroho, A., Hawanti, S., \& Pamungkas, B. T. (2021: 1696). Peran pendampingan yang dilakukan oleh orang tua terhadap anak ketika pembelajaran jarak jauh pastinya memiliki hambatan. Hambatan yang dialami oleh orang tua ketika melakukan pendampingan kepada anak yaitu kendala waktu. Waktu menjadi kendala karena kebanyakan orang tua pasti memiliki pekerjaan sehingga orang tua harus mengatur waktu untuk bisa melakukan pendampingan secara maksimal. Untuk kebanyakan orang tua alasan pekerjaan menjadi salah satu kesulitan yang dialami oleh orang 
tua.

Kendala orang tua dalam pendampingan penanaman sikap disiplin pada pembelajaran jarak jauh selanjutnya yaitu terkait tingkat pemahaman dan penguasaan materi yang dimiliki oleh orang tua. Tingkat pemahaman materi yang rendah oleh orang tua ini akan berdampak buruk ketika anak mengalami kesulitan dan menanyakannya terhadap orang tua, sehingga orang tua mau tidak mau harus mengikuti pembelajaran anak secara teratur sehingga orang tua selalu bisa mendampingi anak dalam pembelajaran jarak jauh. Hambatan yang dialami orang tua sesuai dengan pendapat Nugroho, A., Hawanti, S., \& Pamungkas, B. T. (2021: 1696) hambatan untuk pendampingan siswa dalam pembelajaran jarak jauh selanjutnya yaitu terkait dengan kemampuan orang tua untuk mengetahui materi belajar anak. Pembelajaran yang dilakukan di rumah pastinya anak akan mengalami kesulitan. Kesulitan yang dialami oleh anak menjadikan orang tua sebagai tempat untuk memecahkan masalah, oleh karena itu kemampuan orang tua untuk memahami pada materi pembelajaran anak itu sangat penting sekali supaya anak bisa memecahkan masalah.

Kendala selanjutnya dalam penanaman sikap disiplin dalam pembelajaran jarak jauh oleh orang tua berasal dari lingkungan luar yaitu ketika anak merasa bosan sehingga ketika teman sebayanya main kerumah membuat bimbingan yang diberikan oleh orang tua itu berubah. Peran orang tua yang seharusnya bisa dilakukan hari ini menjadi tertunda karena temannya main di rumah sehingga orang tua mengalah untuk menunda bimbingan yang diberikan. Bimbingan yang diberikan oleh orang tua menjadi terkendala akibat teman yang datang ke rumah untuk bermain sehingga orang tua sesekali untuk mengalah mengikuti kemauan anak untuk bermain dihari itu.

\subsection{Solusi yang dapat dilakukan orang tua dalam pendampingan penanaman sikap disiplin dalam proses pembelajaran jarak jauh di SD N 02 Kemutug Lor}

Hasil penelitian yang telah dilaksanakan di SD N 02 Kemutug Lor menemukan temuan bahwa terdapat beberapa kendala khususnya peran orang tua dalam menanamkan sikap disiplin dalam pembelajaran jarak jauh. Berdasarkan temuan data yang telah dilakukan dapat mengetahui solusi yang dapat dilakukan oleh orang tua untuk bisa membimbing anak supaya memiliki sikap disiplin dalam belajar. Sikap disiplin sangat penting untuk dimiliki anak apalagi ketika pembelajaran dilakukan di rumah, sehingga perlu peranan yang intens oleh orang tua.

Peranan orang tua yang dilakukan dalam penanaman sikap disiplin belajar untuk anak yaitu orang tua harus selalu berkomunikasi dengan anak, komunikasi yang dilakukan harus selalu berjalan dengan baik dan ada timbal balik yang diberikan oleh orang tua. Orang tua ketika anak membutuhkan bantuan orang tua harus selalu ada waktu dan bisa untuk memberikan solusi 
kesulitan yang dialami anak. Solusi yang diberikan orang tua itu berupa komunikasi langsung antara guru dan orang tua sehingga orang tua dalam mendampingi anak bisa berjalan secara efektif dan terkontrol oleh guru secara langsung.

Peranan orang tua yang diberikan pada dasarnya adalah terjadi komunikasi yang baik antara orang tua dengan anak, selalu memberikan bimbingan dan arahan untuk membuat anak selalu tetap memiliki kesibukan dan ketaatan dalam belajar. Orang tua juga ingin membuat les privat yang diberikan oleh guru yang ada disekitarnya, hal ini bertujuan agar anak dapat tetap merasakan suasana belajar seperti tatap muka sehingga diharapkan anak agar tidak bosan karena pembelajaran secara online saja, sehingga anak bisa termotivasi dan menambah semangat belajar dengan demikian pasti sikap kedisiplinan anak akan meningkat terhadap pembelajaran.

Pendamping yang dilakukan untuk menanamkan sikap disiplin kepada anak dalam pembelajaran jarak jauh tidak hanya dari satu komponen saja yaitu orang tua, tetapi guru juga memiliki kontribusi walaupun tidak sebesar orang tua. Peranan yang diberikan guru harus tetap diberikan sehingga terjadinya komunikasi antara guru dan orang tua akan mempermudah guru untuk memberikan pendampingan walaupun secara virtual. Peran yang diberikan guru berupa komunikasi secara langsung dengan siswa, komunikasi yang baik juga kepada orang tua siswa. Guru juga menyempatkan waktu untuk melakukan home visit yang bertujuan untuk mengontrol siswa secara langsung dan mengetahui perkembangan siswa ketika beberapa minggu belajar dengan metode jarak jauh. Kolaborasi yang diberikan oleh guru dan orang tua diharapkan supaya anak bisa selalu menanamkan sikap disiplin dalam pembelajaran jarak jauh

\section{Kesimpulan}

Peran yang diberikan oleh orang tua ketika dirumah yaitu memberikan pendampingan kepada siswa ketika siswa mengalami kesulitan dalam menerima pembelajaran. Orang tua memberikan arahan ketika anak mengalami kesulitan dalam mengerjakan tugas oleh karena itu orang tua mengajari anak untuk bisa memahami materi yang sedang dilaksanakan sehingga anak bisa memahami dan bisa mengerjakan tugas belajar. peranan yang dilakukan oleh orang tua kepada anak ketika pembelajaran jarak jauh di SD N 02 Kemutug Lor yaitu orag tua melakukan pendampingkan kepada siswa dengan selalu menyediakan kebutuhan siswa ketika pembelajaran akan berlangsung. melakukan pendampingan dalam kegiatan pembelajaran jarak jauh terhadap anak tentunya harus memiliki sifat tegas, sifat tegas ini bertujuan untuk membuat anak untuk tetap percaya bahwa orang tua bisa untuk membimbing dirinya ketika melakukan pembelajaran jarak jauh.

Peran orang tua ketika mengawasi anak seharusnya bisa membimbing anak untuk 
memastikan bahwa anak bisa mengikuti pembelajaran dengan baik dan bisa mengerjakan tugas secara tepat waktu. Peran orang tua untuk menanamkan sikap disiplin dalam pembelajaran juga didukung oleh guru dengan pelaksanaan pembelajaran yang selalu diusahakan oleh guru dengan pelaksanaan pembelajaran yang dilakukan tepat waktu sehingga secara tidak lamgsung mengajarkan siswa untuk berperilaku disiplin dalam pembelajaran.

Kendala waktu yang dialalmi oleh orang tua itu berkaitan dengan faktor pekerjaan dari orang tua, ketika orang tua yang memiliki pekerjaan pastinya harus bisa membagi waktu untuk bisa mendampingi anak. Kendala waktu ini menyebabakan orang tua tidak bisa selalu mendampingi anak untuk menerapkan sikap disiplin ketika pembelajaran ataupun tugas dari guru. kendala orang tua dalam pendampingan penanaman sikap disiplin pada pembelajaran jarak jauh selanjutnya yaitu terkait tingkat pemahaman dan penguasaan materi yang dimiliki oleh orang tua. kendala selanjutnya dalam penanaman sikap disiplin dalam pembelajaran jarak jauh oleh orang tua berasal dari lingkungan luar yaitu ketika anak meras bosan sehingga ketika teman sebayanya main kerumah membuat bimbingan yang diberikan oleh orang tua itu berubah mengikuti kemauan anak untuk bermain.

Peranan orang tua yang dilakukan dalam penanaman sikap disiplin belajar untuk anak yaitu orang tua harus selalu berkomunikasi dengan anak, komunikasi yang dilakukan harus selalu berjalan dengan baik dan ada timbal balik yang diberikan oleh orang tua. Orang tua ketika anak membutuhkan bantuan orang tua harus selalu ada waktu dan bisa untuk memberikan solusi kesulitan yang dialami siswa. Orang tua juga ingin mengadakan les privat yang diberikan oleh guru yang ada dalam lingkungan rumah hal ini bertujuan agar anak dapat tetap merasakan suasana belajar seperti tatap muka dan untuk menghilangkan sifat malas dan bosan pada anak

\section{DAFTAR PUSTAKA}

Akmaluddin, \& B. Haqqi. (2019). Kedisiplinan Belajar Siswa di Sekolah Dasar ( SD ) Negeri Cot Keu Eung Kabupaten Aceh Besar (StudiKasus). Journal of Education Science (JES), 5(2), 1-12. Retrieved from file:///C:/Users/7/Downloads/467-554-1-SM.pdf.

Lilawati, A. (2021). Peran Orang Tua dalam Mendukung Kegiatan Pembelajaran di Rumah pada Masa Pandemi. Jurnal Obsesi: Jurnal Pendidikan Anak Usia Dini, 5(1), 549-558. https://doi.org/10.31004/obsesi.v5i1.630.

Mubarok, M. S. (2017). Pengaruh Manajemen Bimbingan dan Konseling Terhadap Disiplin Belajar dalam Mewujudkan Prestasi Belajar Siswa. Khazanah Akademia, 01(01), 49-58.

Nugroho, A., Hawanti, S., \& Pamungkas, B. T. (2021). Kontribusi Orang Tua Dalam Pendampingan Belajar Siswa Selama Masa Pandemi. Jurnal Basicedu, 5(4), 1691-1699. 
Wijayanti, R. M., Fauziah, P. Y. (2021). Perspektif dan Peran Orangtua dalam Program PJJ Masa Pandemi Covid-19 di PAUD. Jurnal Obsesi, 5(2), 1304-1312. 